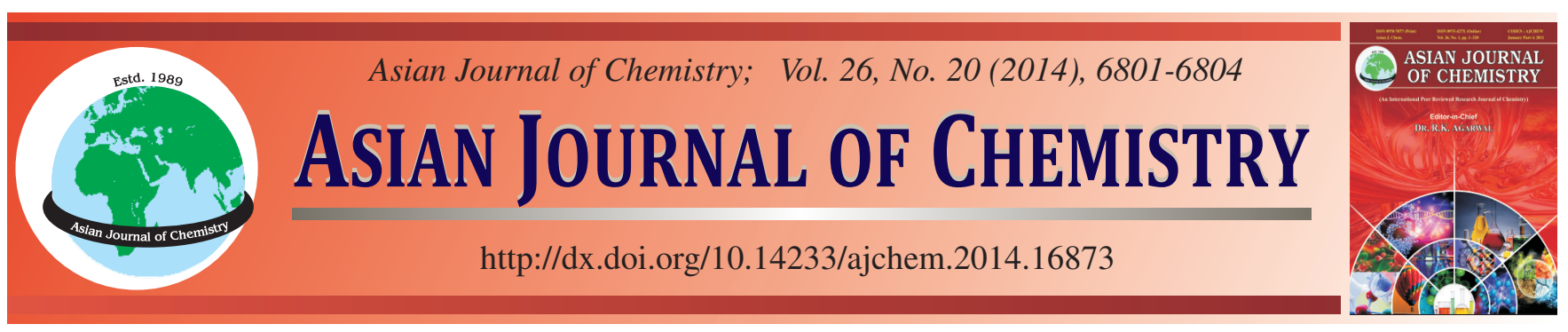

\title{
Photocatalytic Degradation of Acidic Black 10B of Aqueous Solution Using $\mathrm{Ba}_{\mathrm{x}} \mathrm{Sr}_{1-\mathrm{x}} \mathrm{Fe}_{0.5} \mathrm{Co}_{0.5} \mathrm{O}_{3-\delta}$
}

\author{
Jun Qiao, Meilan Chen, Feilin Hao and Xianghong Huang*
}

College of Biology and Environmental Engineering, Zhejiang Shuren University, Hangzhou, Zhejiang, P.R. China

*Corresponding author: Fax: +86 571 88297103; Tel: +86 571 88296952; E-mail: hbeilei@126.com; workhard84@126.com

Two kinds of perovskite $\mathrm{Ba}_{x} \mathrm{Sr}_{1-x} \mathrm{Fe}_{0.5} \mathrm{Co}_{0.5} \mathrm{O}_{3-\delta}(\mathrm{x}=0.2,0.4)$ were prepared by citrate method and were sintered at $850{ }^{\circ} \mathrm{C}$ for $8 \mathrm{~h}$. The obtained products were characterized by X-ray diffraction (XRD), scanning electron microscopy (SEM). The photocatalytic degradation efficiency of acidic black 10B of aqueous solution was evaluated in different reaction conditions under the irradiation of UV. Several operational parameters affecting the photocatalytic degradation of acidic black 10B under the irradiation of UV were studied systematically,including irradiation time, photocatalyst dose, acidic black 10B initial concentration, $\mathrm{pH}$ value of initial acidic black 10B solution and amount of $\mathrm{H}_{2} \mathrm{O}_{2}(1 \%)$ added. The results showed that perovskite-type $\mathrm{Ba}_{x} \mathrm{Sr}_{1-x} \mathrm{Fe}_{0.5} \mathrm{Co}_{0.5} \mathrm{O}_{3-\delta}$ exhibited excellent photocatalytic properties.

Keywords: Photocatalytic degradation, $\mathrm{Ba}_{x} \mathrm{Sr}_{1-x} \mathrm{Fe}_{0.5} \mathrm{Co}_{0.5} \mathrm{O}_{3-\delta}$, Aacidic black 10B, Affecting parameters.

\section{INTRODUCTION}

Azo dyes have been used in the fields of textile, paint, ink and cosmetics ${ }^{1}$. At least $15 \%$ azo dyes were discharged from the waste water of textile and some other relevant industries. These dyes were extremely resistant to microbial degradation and converted to toxic or carcinogenic compounds $\mathrm{s}^{2-4}$. Various technologies have been investigated for the degradation of azo dyes, such as flocculation, carbon adsorption, membrane filtration, ion exchange, reverse osmosis, active sludge processes and advanced oxidation methods $\mathrm{s}^{5-11}$. However, conventional physical and chemical methods were very difficult to destruct completely dye pollutions which would lead to potentially secondary pollution problem ${ }^{12}$. This was because the dye compounds might transfer from aqueous state to other states during the treatment processes.

As a "green" technology, heterogeneous photocatalytic technique has been applied for waste water treatment ${ }^{13}$. The process brings about the complete degradation of most organic pollutants without secondary pollution. Great attention has been paid to develop some novel perovskite photocatalysts to decompose organic dyes by the technology for recent years, because the separation of electrons and holes in the perovskite oxides is easier than that in other semiconductor materials on account of their narrower depletion layers ${ }^{12}$. A series of perovskite-type photocatalysts, such as $\mathrm{Bi}_{2} \mathrm{MoO}_{6}{ }^{13,14}$, $\mathrm{Bi}_{2} \mathrm{Ti}_{4} \mathrm{O}_{11}{ }^{14,15}, \mathrm{BiFeO}_{3}{ }^{16}, \mathrm{Bi}_{2} \mathrm{WO}_{6}{ }^{17}, \mathrm{NaTaO}_{3}{ }^{18}, \mathrm{La}_{2} \mathrm{Ti}_{2} \mathrm{O}_{7}{ }^{19-21}$,
$\mathrm{SrBi}_{2} \mathrm{Nb}_{2} \mathrm{O}_{9}{ }^{22}, \mathrm{Sm}_{2} \mathrm{Ti}_{2} \mathrm{O}_{7} / \mathrm{SmCrO}_{3}{ }^{23}, \mathrm{Ca}_{2} \mathrm{Nb}_{2} \mathrm{O}_{7}{ }^{24}$, have been investigated over their photocatalytic properties and application for degrading dyes.

In this study, the perovskite oxides i.e., $\mathrm{Ba}_{\mathrm{x}} \mathrm{Sr}_{1-\mathrm{x}} \mathrm{Fe}_{0.5} \mathrm{Co}_{0.5} \mathrm{O}_{3-\delta}$ $(\mathrm{x}=0.2,0.4)$, which were synthesized by citric method and sintered at $850{ }^{\circ} \mathrm{C}$, characterized by X-ray diffraction (XRD) and scanning electron microscopy (SEM). Photocatalytic degradation efficiency of acidic black 10B (AB) in aqueous solution using $\mathrm{Ba}_{\mathrm{x}} \mathrm{Sr}_{1-\mathrm{x}} \mathrm{Fe}_{0.5} \mathrm{Co}_{0.5} \mathrm{O}_{3-\delta}(\mathrm{x}=0.2,0.4)$ catalysts was evaluated under different reaction conditions. The effects of irradiation time, catalyst dose, initial concentration and $\mathrm{pH}$ of solution, hydrogen peroxide amount on degrading acidic black 10B efficiency were investigated and the optimum conditions were also studied.

\section{EXPERIMENTAL}

$\mathrm{Ba}\left(\mathrm{NO}_{3}\right)_{2}$ (Chemical Experiment Plant of Shanghai College), $\mathrm{Co}\left(\mathrm{NO}_{3}\right)_{2} \cdot 6 \mathrm{H}_{2} \mathrm{O}$ (Shanghai Reagent Factory Two), $\mathrm{Fe}\left(\mathrm{NO}_{3}\right)_{3} \cdot 9 \mathrm{H}_{2} \mathrm{O}$ (Shanghai Shisihewei chemical industry limited company), $\mathrm{Sr}\left(\mathrm{NO}_{3}\right)_{2}$ (Shanghai Reagent Factory Two) and $50 \%$ excessive citric acid (Hangzhou high crystal fine chemical industry limited company)were mixed and dissolved into deionized water, then polymerized at 90 to $100{ }^{\circ} \mathrm{C}$ for 3 to $4 \mathrm{~h}$. Water was evaporated by heating until the brown gellike products were formed. The products were dried at $120^{\circ} \mathrm{C}$ for $20 \mathrm{~h}$ and the organic compounds in the products were removed in a box furnace (Nabertherm 30-3000) at $400{ }^{\circ} \mathrm{C}$ 
for $2 \mathrm{~h}$. The obtained black powders were ground for $0.5 \mathrm{~h}$ and sintered at $850^{\circ} \mathrm{C}$ for $8 \mathrm{~h}$. The heating or cooling rate was set to be $5^{\circ} \mathrm{C} / \mathrm{min}$.

The structures of the powders were characterized by XRD and the figures were recorded using Dmax-RA (Rigaku) with $\mathrm{CuK}_{\alpha}$ radiation $\left(\lambda=1.5418 \AA\right.$ ) in the $2 \theta$ range of $20-90^{\circ}$. The sample morphology and the particle size of the fine powders were observed by SEM (TM1000, Hitachi).

\section{RESULTS AND DISCUSSION}

Structure and morphology of the prepared photocatalysts

XRD patterns: The XRD patterns of the as-prepared photocatalysts $\mathrm{Ba}_{\mathrm{x}} \mathrm{Sr}_{1-\mathrm{x}} \mathrm{Fe}_{0.5} \mathrm{Co}_{0.5} \mathrm{O}_{3-\delta}(\mathrm{x}=0.2,0.4)$ were showed in Fig. 1. From the figure it could be found that the products were multi-phases. The main crystalline phases of two samples were perovskite-type structures. Due to doping of $\mathrm{Ba}$, it was difficult for the pure cubic structure phase to form completely, as was reported by Shao et $a l .^{26}$. Compared with the XRD patterns of the $\mathrm{Ba}_{0.2} \mathrm{Sr}_{0.8} \mathrm{Fe}_{0.5} \mathrm{CO}_{0.5} \mathrm{O}_{3-\delta}$, more tilt peaks among $32-47^{\circ}$ occurred in the $\mathrm{Ba}_{0.4} \mathrm{Sr}_{0.6} \mathrm{Fe}_{0.5} \mathrm{Co}_{0.5} \mathrm{O}_{3-\delta}$ sample. Moreover, some tilt peaks among $40-47^{\circ}$ were found in the $\mathrm{Ba}_{0.2} \mathrm{Sr}_{0.8} \mathrm{Fe}_{0.5} \mathrm{Co}_{0.5} \mathrm{O}_{3-\delta}$ sample.

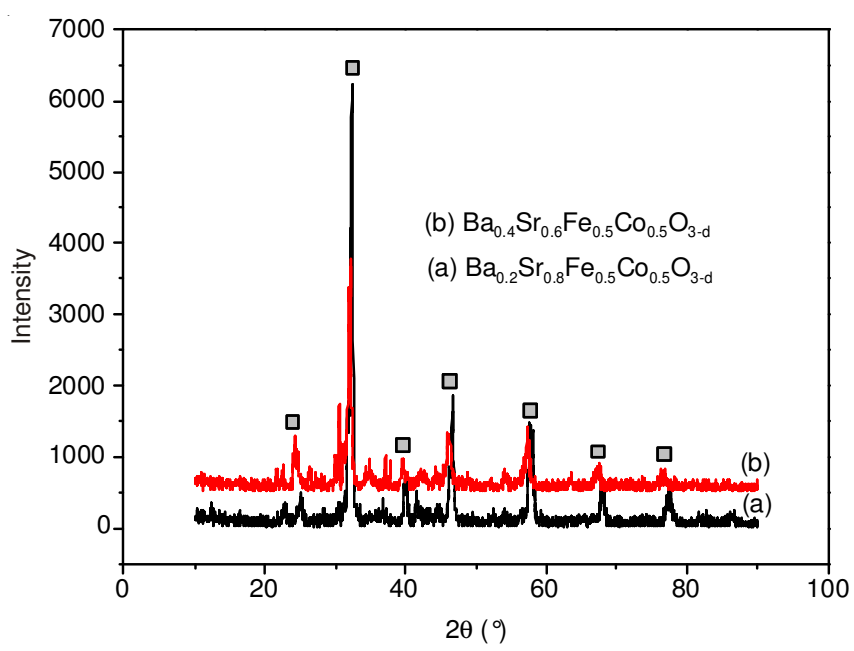

Fig. 1. XRD patterns of the as-prepared samples. (a) $\mathrm{Ba}_{0.2} \mathrm{Sr}_{0.8} \mathrm{Fe}_{0.5} \mathrm{Co}_{0.5} \mathrm{O}_{3-\delta}$, (b) $\mathrm{Ba}_{0.4} \mathrm{Sr}_{0.6} \mathrm{Fe}_{0.5} \mathrm{Co}_{0.5} \mathrm{O}_{3-\delta}$

SEM images: The SEM images of the $\mathrm{Ba}_{0.2} \mathrm{Sr}_{0.8} \mathrm{Fe}_{0.5} \mathrm{Co}_{0.5} \mathrm{O}_{3-\delta}$ and $\mathrm{Ba}_{0.4} \mathrm{Sr}_{0.6} \mathrm{Fe}_{0.5} \mathrm{Co}_{0.5} \mathrm{O}_{3-\delta}$ with different magnifications were displayed in Fig. 2, indicating that the morphologies of the two samples were composed of irregular particles. This is ascribed to various chuck sintered from the cross-linked polymer originated in the citrate process ${ }^{27}$. Some particles with small size are adhesive to those with large size to form the agglomerated particles. The size of two samples was estimated to be $1-10 \mu \mathrm{m}$.

\section{Photocatalytic degradation activity of acidic black 10B}

Effect of irradiation time: The experiments were carried out in the $100 \mathrm{~mL} 10 \mathrm{mg} / \mathrm{L}$ aqueous solution of acidic black 10B with $0.2 \mathrm{~g}$ catalyst. Fig. 3 showed the effect of irradiation time on photocatalytic degradation efficiency of acidic black 10B using $\mathrm{Ba}_{0.2} \mathrm{Sr}_{0.8} \mathrm{Fe}_{0.5} \mathrm{Co}_{0.5} \mathrm{O}_{3-\delta}$ and $\mathrm{Ba}_{0.4} \mathrm{Sr}_{0.6} \mathrm{Fe}_{0.5} \mathrm{Co}_{0.5} \mathrm{O}_{3-\delta}$. It can be easily seen that the photocatalytic degrading acidic black
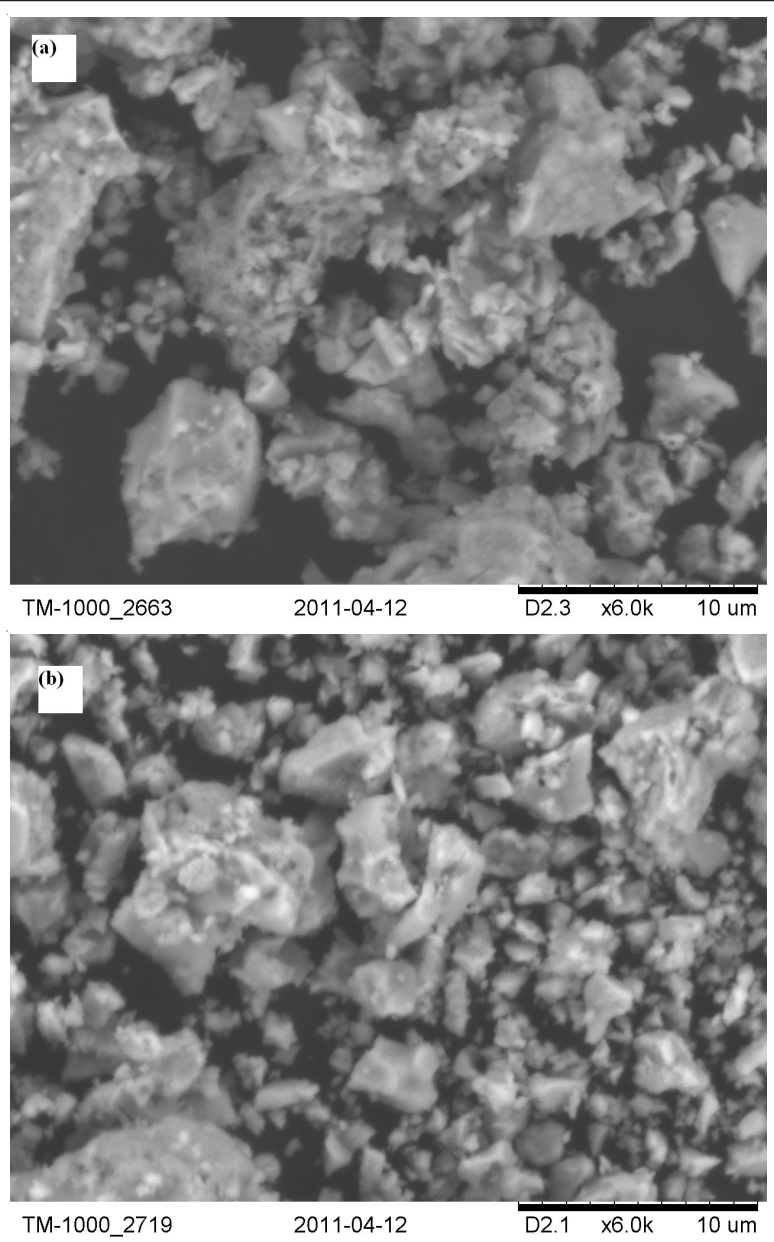

Fig. 2. SEM images of the samples. (a) $\mathrm{Ba}_{0.2} \mathrm{Sr}_{0.8} \mathrm{Fe}_{0.5} \mathrm{Co}_{0.5} \mathrm{O}_{3-\delta}$, (b) $\mathrm{Ba}_{0.4} \mathrm{Sr}_{0.6} \mathrm{Fe}_{0.5} \mathrm{Co}_{0.5} \mathrm{O}_{3-\delta}$

10B efficiency increased with the increasing irradiation time. The photocatalytic activity of the $\mathrm{Ba}_{0.2} \mathrm{Sr}_{0.8} \mathrm{Fe}_{0.5} \mathrm{Co}_{0.5} \mathrm{O}_{3-\delta}$ was slightly better than that of the $\mathrm{Ba}_{0.4} \mathrm{Sr}_{0.6} \mathrm{Fe}_{0.5} \mathrm{Co}_{0.5} \mathrm{O}_{3-\delta}$. This could be explained that doped $\mathrm{Ba}$ with small radius induced the structure defect of the materials and resulted in producing more hole-electron pairs. The maximum degradation efficiency was $92.35 \%$ for irradiation $50 \mathrm{~min}$ using photocatalyst $\mathrm{Ba}_{0.2} \mathrm{Sr}_{0.8} \mathrm{Fe}_{0.5} \mathrm{Co}_{0.5} \mathrm{O}_{3-\delta}$ and $87.43 \%$ for $60 \mathrm{~min}$ using $\mathrm{Ba}_{0.4} \mathrm{~S}_{\mathrm{r} 0.6} \mathrm{Fe}_{0.5} \mathrm{Co}_{0.5} \mathrm{O}_{3-\delta}$, respectively.

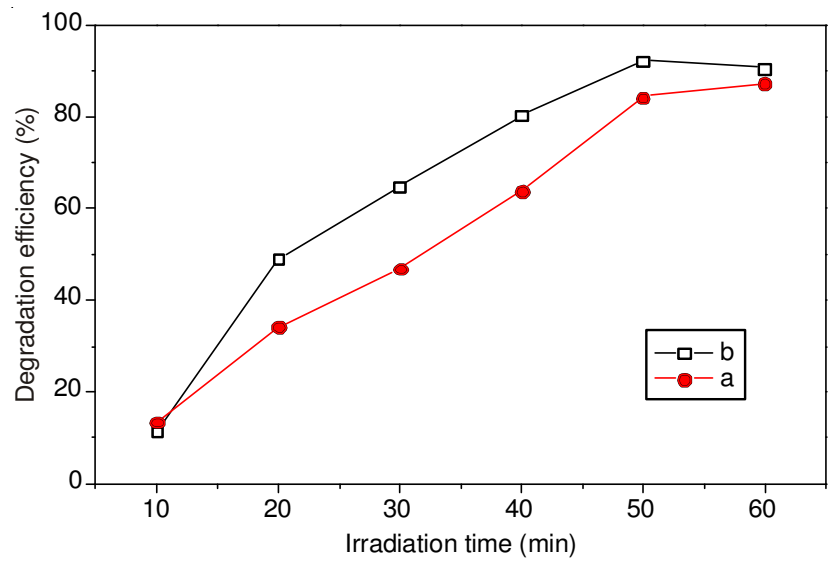

Fig. 3. Effect of the irradiation time on the photocatalytic degradation efficiency of acidic black 10B. (a) $\mathrm{Ba}_{0.2} \mathrm{Sr}_{0.8} \mathrm{Fe}_{0.5} \mathrm{Co}_{0.5} \mathrm{O}_{3-\delta}$, (b) $\mathrm{Ba}_{0.4} \mathrm{Sr}_{0.6} \mathrm{Fe}_{0.5} \mathrm{Co}_{0.5} \mathrm{O}_{3-\delta}$ 
Effect of the dose of photocatalyst: In order to optimize the catalyst dose, catalyst dose was varied from $0.08 \mathrm{~g}$ to 0.22 $\mathrm{g}$ in $100 \mathrm{~mL} 10 \mathrm{mg} / \mathrm{L}$ of aqueous solution of acidic black 10B for $50 \mathrm{~min}$. Fig. 4 exhibited the photocatalytic degradation efficiency of acidic black 10B using different catalyst doses. The results revealed that the photocatalytic activity of the $\mathrm{Ba}_{0.2} \mathrm{Sr}_{0.8} \mathrm{Fe}_{0.5} \mathrm{Co}_{0.5} \mathrm{O}_{3-\delta}$ was always better than that of the $\mathrm{Ba}_{0.4} \mathrm{Sr}_{0.6} \mathrm{Fe}_{0.5} \mathrm{Co}_{0.5} \mathrm{O}_{3-\delta}$ in the given dose range. It can be seen that the photocatalytic activity increases rapidly with the increasing catalyst dose from 0.08 to $0.2 \mathrm{~g}$. As the catalyst dose was over $0.2 \mathrm{~g}$, the photocatalytic degrading acidic black 10B activity of the catalyst increased very slowly because the higher catalysts resulted from the agglomeration of the activated molecules and blocked some light radiation penetration. The maximum efficiency of degrading acidic black 10B is $96.17 \%$ when $0.22 \mathrm{~g} \mathrm{Ba}_{0.2} \mathrm{Sr}_{0.8} \mathrm{Fe}_{0.5} \mathrm{Co}_{0.5} \mathrm{O}_{3-8}$ is added to the $100 \mathrm{~mL}$ aqueous solution of acidic black 10B. However, the maximum degradation efficiency is $85.25 \%$ using $\mathrm{Ba}_{0.4} \mathrm{Sr}_{0.6} \mathrm{Fe}_{0.5} \mathrm{Co}_{0.5} \mathrm{O}_{3-\delta}$ in the same way.

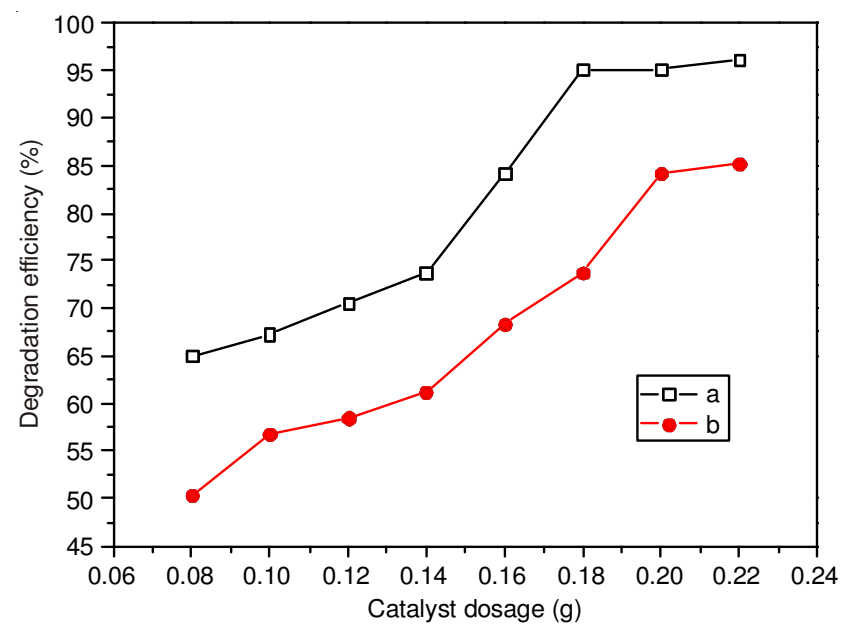

Fig. 4. Effect of catalyst dosage on the photocatalytic degradation efficiency of acidic black 10B, (a) $\mathrm{Ba}_{0.2} \mathrm{Sr}_{0.8} \mathrm{Fe}_{0.5} \mathrm{Co}_{0.5} \mathrm{O}_{3-\mathrm{d}}$, (b) $\mathrm{Ba}_{0.4} \mathrm{Sr}_{0.6} \mathrm{Fe}_{0.5} \mathrm{Co}_{0.5} \mathrm{O}_{3-\delta}$

Effect of initial acidic black 10B concentration: The experiments were performed by varying acidic black 10B initial concentration from 5 to $15 \mathrm{mg} / \mathrm{L}$ for $50 \mathrm{~min}$ irradiation in $100 \mathrm{~mL}$ with $0.18 \mathrm{~g}$ catalyst. Fig. 5 displayed the photocatalytic degradation efficiency of acidic black 10B in different initial acidic black 10B concentration solution. The results indicated that the photocatalytic degrading acidic black 10B efficiency was higher at lower initial catalyst concentration. Compared with these two curves, it can be found that the photocatalytic activity of the $\mathrm{Ba}_{0.2} \mathrm{Sr}_{0.8} \mathrm{Fe}_{0.5} \mathrm{Co}_{0.5} \mathrm{O}_{3-\delta}$ is slightly better than that of the $\mathrm{Ba}_{0.4} \mathrm{Sr}_{0.6} \mathrm{Fe}_{0.5} \mathrm{Co}_{0.5} \mathrm{O}_{3-\delta}$. The maximum degradation efficiency is 95.08 and $91.40 \%$ when the initial concentration of acidic black $10 \mathrm{~B}$ was 10 and $7.5 \mathrm{mg} / \mathrm{L}$ using the $\mathrm{Ba}_{0.2} \mathrm{Sr}_{0.8} \mathrm{Fe}_{0.5} \mathrm{Co}_{0.5} \mathrm{O}_{3-\delta}$ and $\mathrm{Ba}_{0.4} \mathrm{Sr}_{0.6} \mathrm{Fe}_{0.5} \mathrm{Co}_{0.5} \mathrm{O}_{3-\delta}$, respectively. Then the photocatalytic efficiency has a sharp decrease when continue to increase the initial concentration over the optimum. As the initial concentration of dye increased, more dye molecules covered over the surface of the catalysts and therefore hindered the adsorption of the light by photocatalysts, reducing the action of the photocatalysts and resulting in the lower photocatalytic efficiency.

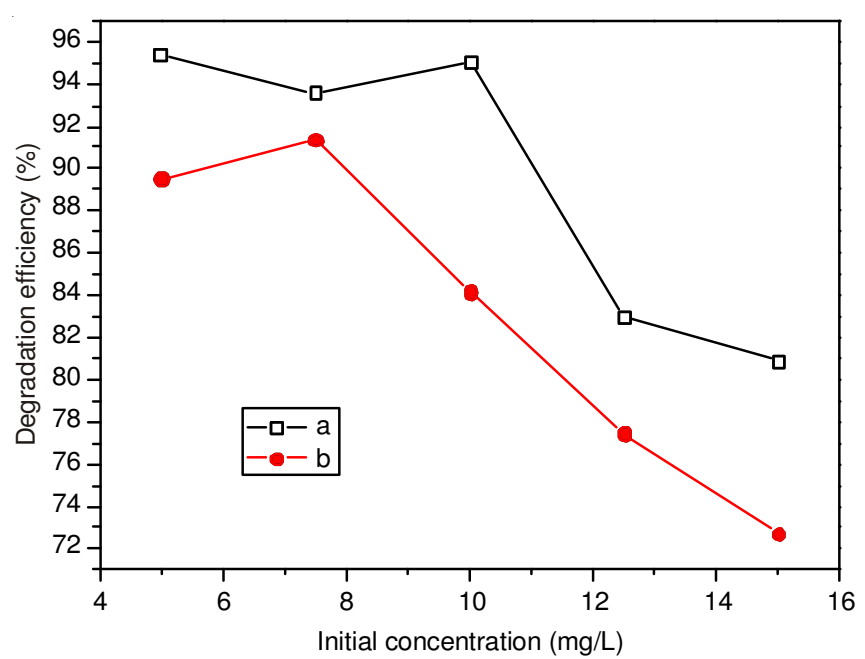

Fig. 5. Effect of the initial catalyst concentration on the photocatalytic degradation efficiency of acidic black 10B. (a) $\mathrm{Ba}_{0.2} \mathrm{Sr}_{0.8} \mathrm{Fe}_{0.5} \mathrm{Co}_{0.5} \mathrm{O}_{3-}$ , (b) $\mathrm{Ba}_{0.4} \mathrm{Sr}_{0.6} \mathrm{Fe}_{0.5} \mathrm{Co}_{0.5} \mathrm{O}_{3-\mathrm{d}}$

Effect of the initial solution with different $\mathrm{pH}$ value: Fig. 6 showed the photocatalytic degradation efficiency with different $\mathrm{pH}$ value varied from 3.1 to 6.98 for 50 min irradiation in 100 $\mathrm{mL}$ of $10 \mathrm{mg} / \mathrm{L}$ of aqueous solution of acidic black 10B with $0.18 \mathrm{~g}$ catalyst. It can be seen that the photocatalytic activity of the $\mathrm{Ba}_{0.4} \mathrm{Sr}_{0.6} \mathrm{Fe}_{0.5} \mathrm{Co}_{0.5} \mathrm{O}_{3-\delta}$ decreases sharply with the increase of the $\mathrm{pH}$ value. However, the photocatalytic activity of the $\mathrm{Ba}_{0.2} \mathrm{Sr}_{0.8} \mathrm{Fe}_{0.5} \mathrm{Co}_{0.5} \mathrm{O}_{3-\delta}$ increases slightly with the increase of the $\mathrm{pH}$ varied from 3.1 to 5.39 and then behaves a rapid drop. Compared with the two curves, the photocatalytic activity for degrading acidic black $10 \mathrm{~B}$ using the $\mathrm{Ba}_{0.2} \mathrm{Sr}_{0.8} \mathrm{Fe}_{0.5} \mathrm{Co}_{0.5} \mathrm{O}_{3-\delta}$ is better than that using $\mathrm{Ba}_{0.4} \mathrm{Sr}_{0.6} \mathrm{Fe}_{0.5} \mathrm{Co}_{0.5} \mathrm{O}_{3-\delta}$. The maximum degradation efficiency is $96.72 \%$ at $\mathrm{pH}=3.1$, indicating that the raising acidity of the solution is beneficial to the photocatalytic reaction of acidic black $10 \mathrm{~B}$.

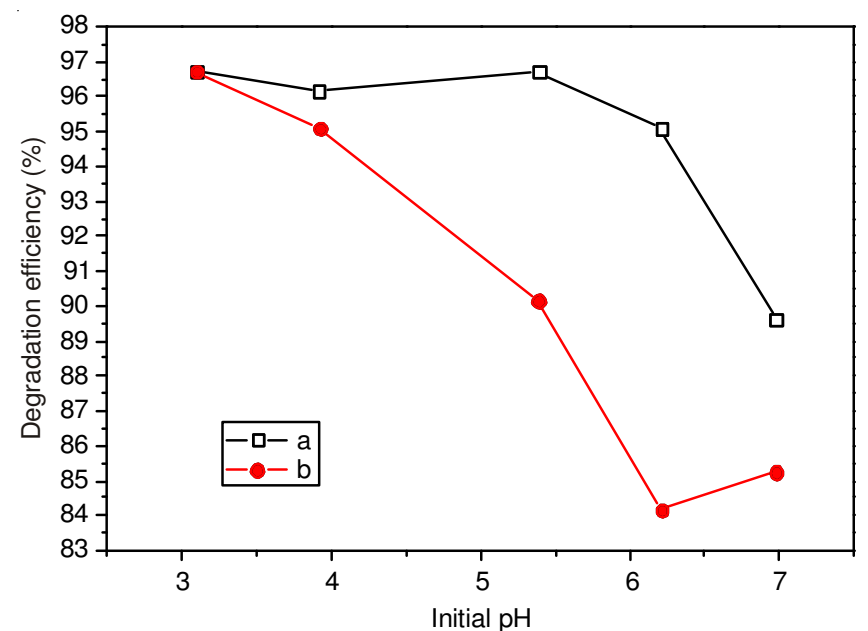

Fig. 6. Effect of initial $\mathrm{pH}$ on the photocatalytic degradation efficiency of acidic black 10B. (a) $\mathrm{Ba}_{0.2} \mathrm{Sr}_{0.8} \mathrm{Fe}_{0.5} \mathrm{Co}_{0.5} \mathrm{O}_{3-\delta}$; (b) $\mathrm{Ba}_{0.4} \mathrm{Sr}_{0.6} \mathrm{Fe}_{0.5} \mathrm{Co}_{0.5} \mathrm{O}_{3-\delta}$

Effect of the amount of hydrogen peroxide solution: The experiments were performed by varying the amount of $1 \% \mathrm{H}_{2} \mathrm{O}_{2}$ from 0.1 to $0.6 \mathrm{~mL}$ for 50 min irradiation in $100 \mathrm{~mL}$ of $10 \mathrm{mg} / \mathrm{L}$ of acidic black $10 \mathrm{~B}$ solution with $0.18 \mathrm{~g}$ catalyst. Fig. 7 showed that the photocatalytic degradation efficiency 
of acidic black 10B increased rapidly with the increase amount of hydrogen peroxide solution at first step from 0.1 to $0.4 \mathrm{~mL}$. Afterwards the photocatalytic activity increased slowly. $\mathrm{H}_{2} \mathrm{O}_{2}$ is a strong oxidant that can generate some strong oxidative free radical $\mathrm{OH}^{\bullet} . \mathrm{H}_{2} \mathrm{O}_{2}$ can also capture electron which may decrease the combination of $\mathrm{e}-\mathrm{h}^{+}$. Consequently, the small amount of hydrogen peroxide promotes the formation of the free radical $\mathrm{OH}^{\bullet}$ and thus improves the photocatalytic degradation efficiency.

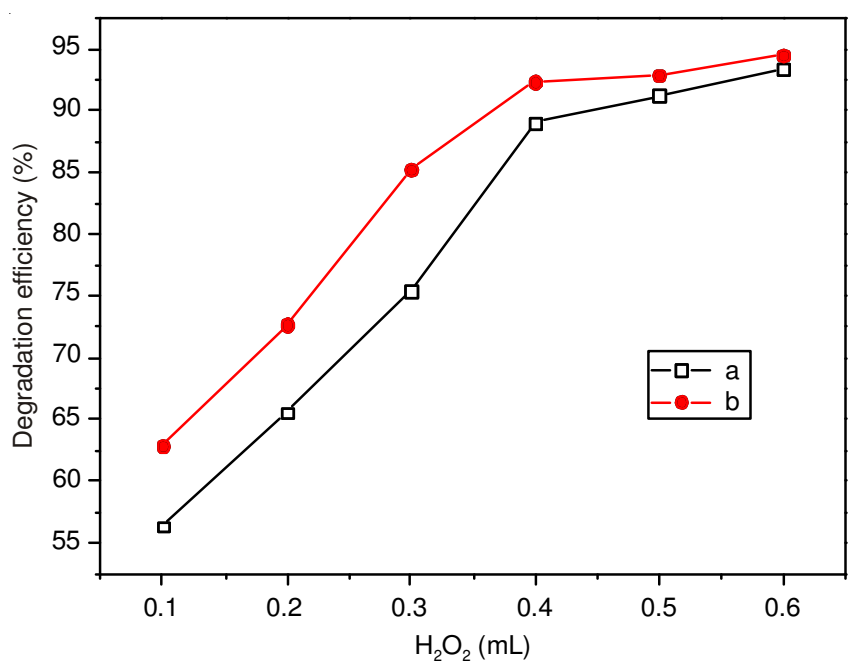

Fig. 7. Effect of the $\mathrm{H}_{2} \mathrm{O}_{2}$ amount on the photocatalytic degradation efficiency of the acidic black 10B. (a) $\mathrm{Ba}_{0.2} \mathrm{Sr}_{0.8} \mathrm{Fe}_{0.5} \mathrm{Co}_{0.5} \mathrm{O}_{3-\delta}$, (b) $\mathrm{Ba}_{0.4} \mathrm{Sr}_{0.6} \mathrm{Fe}_{0.5}-\mathrm{Co}_{0.5} \mathrm{O}_{3-\delta}$

Mechanism of the photocatalytic degradation: The possible mechanism has been suggested by previous reports ${ }^{25,28}$. The separation and transporting rate of the photogenerated electrons and holes in the catalyst play important role in the overall catalytic activity of photocatalyst. The separation of electrons and holes in the perovskite is easier than that in other semiconductors because of their narrower depletion layers ${ }^{29}$. When the perovskite-type $\mathrm{Ba}_{\mathrm{x}} \mathrm{Sr}_{1-\mathrm{x}} \mathrm{Fe}_{0.5} \mathrm{Co}_{0.5} \mathrm{O}_{3-\delta}$ photocatalysts were irradiated by light with energy larger than its band gap, electron/hole pairs would generated and be effectively separated. The electrons and holes transfer along the crystalline lattice to the surface of the photocatalysts and then react with water and dissolved oxygen molecules to generate several oxygen active species, such as $\mathrm{OH}^{\bullet}, \mathrm{OH}_{2}{ }^{\bullet}, \mathrm{O}_{2}{ }^{--}$, etc. Hydroxyl radical $\left(\mathrm{OH}^{\circ}\right)$ is considered to be a key non-selective species in the photodegradation of hazardous compounds because of its high reaction ability to attack any organic molecules ${ }^{30}$. The hydroxyl radical $\left(\mathrm{OH}^{*}\right)$ react with acidic black 10B causing a series of oxidative reactions and ultimately mineralize the acid black $10 \mathrm{~B}$ to $\mathrm{H}_{2} \mathrm{O}$ and $\mathrm{CO}_{2}$, etc.

\section{Conclusion}

Both $\mathrm{Ba}_{0.2} \mathrm{Sr}_{0.8} \mathrm{Fe}_{0.5} \mathrm{Co}_{0.5} \mathrm{O}_{3-\delta}$ and $\mathrm{Ba}_{0.4} \mathrm{Sr}_{0.6} \mathrm{Fe}_{0.5} \mathrm{Co}_{0.5} \mathrm{O}_{3-\delta}$ can degrade acidic black 10B efficiently under light irradiation. Compared with the catalyst $\mathrm{Ba}_{0.4} \mathrm{Sr}_{0.6} \mathrm{Fe}_{0.5} \mathrm{Co}_{0.5} \mathrm{O}_{3-\delta}$, $\mathrm{Ba}_{0.2} \mathrm{Sr}_{0.8} \mathrm{Fe}_{0.5} \mathrm{Co}_{0.5} \mathrm{O}_{3-\delta}$ exhibited slightly higher photocatalytic activity. The photocatalytic degradation efficiency were affected by irradiation time, photocatalyst dose, initial concentration of acidic black 10B, pH value of initial acidic black 10B solution and the amount of $\mathrm{H}_{2} \mathrm{O}_{2}$. The optimum irradiation time, photocatalyst dose, initial concentration of acidic black $10 \mathrm{~B}, \mathrm{pH}$ value of initial acidic black 10Bsolution and the amount of $\mathrm{H}_{2} \mathrm{O}_{2}$ were $50 \mathrm{~min}, 0.22 \mathrm{~g}, 7.5 \mathrm{mg} / \mathrm{L}, 3.1$ and 0.6 $\mathrm{mL}$ in $100 \mathrm{~mL}$ aqueous solution of acidic black 10B with $\mathrm{Ba}_{0.2} \mathrm{Sr}_{0.8} \mathrm{Fe}_{0.5} \mathrm{Co}_{0.5} \mathrm{O}_{3-\delta}$, respectively. However, the optimum irradiation time was 60 min for $\mathrm{Ba}_{0.4} \mathrm{Sr}_{0.6} \mathrm{Fe}_{0.5} \mathrm{Co}_{0.5} \mathrm{O}_{3-\delta}$.

\section{ACKNOWLEDGEMENTS}

This work was supported by Zhejiang Province Nature Science Foundation of China ((LY12BO3010), Zhejiang Province Science and Technology Project of China (2010 C31G2220021).

\section{REFERENCES}

1. C. Sahoo, A.K. Gupta and A. Pal, Desalination, 181, 91 (2005).

2. S.A. Ong, K. Uchiyama, D. Inadama and K. Yamagiwa, J. Hazard. Mater., 165, 696 (2009).

3. F. Han, V.S.R. Kambala, M. Srinivasan, D. Rajarathnam and R. Naidu, Appl. Catal. A, 359, 25 (2009).

4. W.J. Lau and A.F. Ismail, Desalination, 245, 321 (2009).

5. F. Herrera, A. Lopez, G. Mascolo, P. Albers and J. Kiwi, Water Res., 35, 750 (2001).

6. W.Z. Tang and H. An, Chemosphere, 31, 157 (1995).

7. V. Meshko, L. Markovska, M. Mincheva and A.E. Rodrigues, Water Res., 35, 3357 (2001).

8. W.S. Kuo and P.H. Ho, Chemosphere, 45, 77 (2001).

9. C. Galindo, P. Jacques and A. Kalt, Chemosphere, 45, 997 (2001).

10. J. Tang, Z. Zou, J. Yin and J. Ye, Chem. Phys. Lett., 382, 175 (2003).

11. W.F. Yao, X.H. Xu, H. Wang, J.T. Zhou, X.N. Yang, Y. Zhang, S.X. Shang and B.B. Huang, Appl. Catal. B, 52, 109 (2004).

12. P. Wongkalasin, S. Chavadej and T. Sreethawong, Colloids Surf. A, 384, 519 (2011).

13. J.H. Bi, L. Wu, J. Li, Z.H. Li, X.X. Wang and X.Z. Fu, Acta Mater., 55, 4699 (2007).

14. T.K. Ghorai, D. Dhak, S. Dalai and P. Pramanik, Mater. Res. Bull., 43, 1770 (2008).

15. T.K. Ghorai, D. Dhak, S. Dalai and P. Pramanik, J. Alloys Comp., 463, 390 (2008).

16. Y.N. Huo, Y. Jin and Y. Zhang, J. Mol. Catal. Chem., 331, 15 (2010).

17. S.O. Alfaro and A. Martínez-de la Cruz, Appl. Catal. A, 383, 128 (2010).

18. D.R. Liu, Y.S. Jiang and G.M. Gao, Chemosphere, 83, 1546 (2011).

19. Y. Ku, L.C. Wang, C.M. Ma and Y.C. Chou, Water Air Soil Pollut., 215, 97 (2011).

20. W.M. Hou and Y. Ku, J. Alloys Comp., 509, 5913 (2011).

21. K. Onozuka, Y.H. Kawakami, H. Imai, T. Yokoi, T. Tatsumi and J.N. Kondo, J. Solid State Chem., 192, 87 (2012).

22. J.-H. Kim, K.-T. Hwang, U.-S. Kim and Y.-M. Kang, Ceram. Int., 38, 3901 (2012).

23. A. Nashim and K.M. Parida, Chem. Eng. J., 215-216, 608 (2013).

24. S.J. Liang, L.R. Wen, G.D. Liu, S.Y. Zhu, R. Yuan and L. Wu, Catal. Today, 201, 175 (2013).

25. Y.H. Yang, Q.Y. Chen and Z.L. Yin, J. Chin. Rare Earth Soc., 22, 647 (2004).

26. Z. Shao, G. Xiong, J. Tong, H. Dong and W. Yang, Sep. Purif. Technol., 25, 419 (2001).

27. X.H. Huang, L.Z. Pei, C.G. Fan and Q.F. Zhang, Inorg. Mater., 46, 1225 (2010)

28. A. Martínez-de la Cruz and S. Obregón Alfaro, J. Mol. Catal. A, 320, 85 (2010).

29. X.H. Huang, J. Qiao and Q.F. Zhang, Adv. Mater. Res., 549, 141 (2012).

30. M.R. Hoffmann, S.T. Martin, W. Choi and D.W. Bahnemann, Chem. Rev., 95, 69 (1995). 